\title{
Nutrient Absorption by the Submerged Macrophyte Egeria densa Planch.: Effect of Ammonium and Phosphorus Availability in the Water Column on Growth and Nutrient Uptake
}

\author{
Claudia Feijoó', María Eugenia García ${ }^{1}$, Fernando Momo ${ }^{1}$ and Julia Toja² \\ 'Programa de Ecología Acuática, Universidad Nacional de Luján, C.C. 221, (6700) Luján, Argentina. \\ ${ }^{2}$ Departamento de Ecología, Facultad de Biología, Universidad de Sevilla, Sevilla, España.
}

\begin{abstract}
The relative importance of phosphorus and nitrogen absorption from water and sediments by Egeria densa Planch. (Hydrocharitaceae), a subinerged macropliyte very common in Pampean streams in Argentina, was experimentally assessed. Two experiments were performed to determine the importance of water as opposed to sediment source of phosphorus, and to investigate the effect oftype of nitrogenouc ion dissolved in water on nitrogen uptake by this species.

In the first experiment, the concentration of soluble reactive phosphorus in water had an effect on $E$. densa biomacc and on tissular phocphoruc concentrations. Absorption rates of phocphorus from water were higher than from the sediment. In a separate experiment, we found that $E$. densa absorbed more nitrogen from water when it was precent as ainmonium than when it was present as nitrate. Thic differential absorption increased total nitrogen concentration in the macrophytic tissues, but biomacc yield was not affected. Nitrogen uptake from the cediment was negligible.

In our experiments, absorption rates from water and sediments were higher for phosphorus than for nitrogen. This suggests that mechanicms of uptake and retention are more efficient for phosphorus than for nitrogen in $E$. densa.
\end{abstract}

Key words: Macrophytes, phosphorus, nitrogen, cediments, Egeria densa

\begin{abstract}
Resumen
El objetivo de este trabajo es evaluar experimentalmente la importancia relativa de la absorción de fósforo y nitrógeno del agua y de los sedimentos en Egeria densa Planch. (Hydrocharitaceae), un macrófito sumergido muy común en arroyos pampeanos. Se realizaron dos experienciaspara determinar la importancia del agua como fuente de fósforo, y también para determinar la influencia del tipo de ion nitrogenado presente en agua sobre la absorción de nitrógeno en esta especie.

En el primer experimento. diferentes concentraciones de fósforo reactivo soluble en agua produjeron diferentes biomasas y concentraciones tisulares de fósforo en $\mathrm{E}$. densa. Las tasas de absorción de fósforo del agua fueron mayores que las del sedimento. En el otro experimento, observamos que E. densa absorbe más nitrógeno del agua en forma de amonio que como nitrato. Esta absorción diferencial aumenta la concentración tisular de nitrógeno. pero no incrementa la biomasa macrofitica. No se detectó absorción significativa de nitrógeno del sedimento.

En nuestros experimentos, las tasas de absorción del agua y del sedimento fueron mayores para el fósforo que para el nitrógeno. Esto sugiere que los mecanismos de captación y de retención son más eficientes para el fósforo que para el nitrógeno en E. densa
\end{abstract}

Palabras clave: Macrófitos, fósforo, nitrógeno, sedimento. Egeria densa. 


\section{INTRODUCTION}

Submerged macrophytes have major effects on productivity and biogeochemical cycling in aquatic environments because they represent a link between the sediments and the overlying water (Duarte et al., 1994). Rooted submerged macrophytes can absorb nutrients from both the water and the sediinents, but it is generally considered that sediments are the main source of both phosphorus and nitrogen (Carpenter \& Lodge, 1986; Barko et al., 1991).

Egeria densa Planch. is a submerged macrophyte native to South Anierica, widely distributed in streams of the NE Pampean plain (Argentina). This species has long shoots with small and thin leaves, and adventitious roots. New plants are produced by fragmentation of old shoots: plant fragments can sink in the stream bottom and then produce roots, which allow the attachment to the sediments (Getsinger, 1982). In macrophyte stands of Pampean streams, we have also observed healthy plants without roots.

In a previous field study examining factors which may influence $E$. densa biomass in a Pampean stream, we observed that both plant biomass and nutrient content in plant tissue of $E$. densa were positively correlated with nutrient concentrations in water (i.e. soluble reactive phosphorus and ammonium) and in sediments (i.e. total nitrogen) (Feijoó et al., 1996). Following up on these results, we designed two experiments to evaluate the relative magnitude of phosphorus and nitrogen absorption from water and sediments by $E$. densa. Main aims of these experiments were:

Experiment I: To determine the importance of water as source of phosphorus to $E$. densa.

Experiment II: To determine the influence of the type of nitrogenous ion (i.e. NO; vs. NH,') dissolved in water on nitrogen absorption by $E$. densa.

\section{METHODS}

\section{General experimental procedures}

The experiments were conducted in a greenhouse located at the Universidad Nacional de Luján, Buenos Aires (Argentina). Knop solution (dilution 1:8) was used as the medium for nutrient $(\mathrm{N}$ $\& \mathrm{P})$ additions, because it has been used successfully to grow $E$. densa in the past (Caso, 1954).

$E$. densa shoots and sediments used in the experiments were collected from Las Flores stream, a third-order Pampean stream. Sediments were primarily fine silt and clay, with a low content in sand and absence of pebbles and stones.

Although plant shoots were rinsed before use in experiments and periphyton growth was not apparent, it is still possible that some algae remained attached to the shoots. Consequently, when we refer to nutrient absorption by $E$. densa we are considering the complex macrophyte-periphyton.

Tabla 1. Methods used for the determination of physical and chemical variables in nutrient-absorption laboratory experiments performed on the macrophyte Egeria densa Planch. Técnicas utilizadas para la determinación de diferentes variables en los experimentos realizados con el macrófito Egeria densa Planch.

\begin{tabular}{lll}
\hline Variable & Method & Reference \\
\hline Soluble reactive phosphorus & Ascorbic acid & APHA, 1992 \\
Nitrates & Cadmium reduction & APHA, 1992 \\
Nitrites & Diazotization & APHA, 1992 \\
Ammonium & Koroleff & Wetzel \& Likens, 1991 \\
Total phosphorus in cediment & Ascorbic acid (previous & Andersen, 1916; AOAC, \\
and plant tissue & digestion with HCl) & 1984; APHA, 1992. \\
Total nitrogen in sediment and & Semimicrokjeldahl & AOAC, 1984; FAO, 1986. \\
plant tissue & & Wetzel \& Likens, 1991 \\
$E$. densa biomass & Dry weigth & \\
\hline
\end{tabular}


Glass vessels (3-L) were filled with 2.5-L Knop solution. A plastic pot $7 \mathrm{~cm}$ in diameter with $90 \mathrm{~g}$ of sediment was placed inside each vessel. The sediment was covered with plastic film and a 1$\mathrm{cm}$ sand layer. The sand had been washed with $5 \%$ HCI, to avoid the exchange of nutrients between sediments and water (Best et al., 1996). Six $18-\mathrm{cm}$ long apical shoots of $E$. densa were inserted into the sediment. Control vessels, without plant shoots, were also prepared to determine whether nutrient concentrations in water and sediments changed for reasons other than nutrient absorption by $E$. densa.

Experiments lasted for 7 days. Water temperature and dissolved oxygen concentration were measured in each vessel every 48 hours using a Luftman sensor and an Oxys oximeter, respectively. E. densa biomass (grams dry weight, g DW) and nutrient concentrations ( $\mathrm{N} \&$ P species) in water, sediments and plants were determined according to the techniques listed in Table 1 . Total nutrient content in plant tissues was estimated by multiplying nutrient concentration in tissues by plant biomass. Interstitial water was separated from sediment by high-speed centrifugation at $4{ }^{\circ} \mathrm{C}$ (Barko \& Smart, 1986). This water was then passed through Whatman GF/C filters, and soluble reactive phosphorus (SRP) and ammonium concentrations were measured in the filtrates.

Phosphorus and nitrogen absorption rates in $E$. densa were estimated using the following equation:

$$
\frac{N_{t}+N_{i}}{\mathrm{~B} \times \mathrm{t}} \times \frac{1}{\bar{N}}
$$

where:

$N_{f}=$ nutrient content (in mg) in water or sediments at the end of the experiment.

$N_{i}=$ nutrient content (in $\mathrm{mg}$ ) in water or sediments at the beginning of the experiment.

$\bar{N}=\left(N_{f}+N_{j} / 2\right.$ (in mg)

$B=$ initial biomass of $E$. densa $(\mathrm{g} \mathrm{DW})$.

$\mathrm{t}=$ time (days)

In the calculation of $\mathrm{N}$ absorption rates from water, $\mathrm{N}$ content (in $\mathrm{mg}$ ) was estimated as the sum of nitrate, nitrite and ammonium contents.
Absorption rates from sediments were estimated using total phosphorus (TP) and total nitrogen (TN) contents.

Statistical significance of differences among treatments was assessed by the Kruskal-Wallis ANOVA by ranks (Siegel, 1986).

\section{Experiment 1: phosphorus absorption}

Apical shoots of $E$. densa were exposed to two water SRP concentrations ( $P^{+}$and $P$ ) SRP concentration in the $P^{+}$treatment was the mean SRP concentration observed in the Las Flores stream (i.e. $0.3 \mathrm{mg} \mathrm{P-PO}, 1^{-1}$ ) (Feijoó et al, 1996), while SRP concentration in the $P$-treatment was half of this value (i.e. $0.15 \mathrm{mg}$ P-PO, $1^{-1}$ ). The nutrient medium also contained nitrogen as nitrate at a concentration similar to the highest dissolved inorganic nitrogen concentration observed in the Las Flores stream (i.e. $7.1 \mathrm{mg} \mathrm{N}-\mathrm{NO}, \mathrm{I}^{-1}$ ). Ten vessels were prepared, 4 replicates of each treatment, plus a $\mathrm{P}^{+}$control, and a $\mathrm{P}^{-}$control (see Table 2).

Water SRP concentration was measured in each treatment at the beginning of the experiment. Initial values of macrophytic biomass, phosphorus concentration in plant and sediments, and interstitial-water phosphorus concentration were determined in 4 independent replicate samples of plant and sediment. The same measurements were made at the end of the experiment.

\section{Experiment 11: nitrogen absorption}

Apical shoots of $E$. densa were exposed to 4 treatments. A total of 15 vessels were prepared, i.e. 3 vessels with Knop solution without nitrogen (i.e. the $\mathrm{H}_{2} \mathrm{O}$ treatment), 3 vessels with Knop solution with nitrate (i.e. the $\mathrm{NO}_{3}^{-}$treatment), 6 vessels with Knop solution with ammonium (i.e. $\mathrm{NH}_{4}{ }^{-} \mathrm{S}$ and $\mathrm{NH}_{4}{ }^{\prime} \mathrm{A}$ treatments), and 2 vessels with distilled water (controls) (Table 2). The $\mathrm{NH}_{4}{ }^{+} \mathrm{S}$ and $\mathrm{NH}_{4}{ }_{4} \mathrm{~A}$ treatments differed in that substrate in the $\mathrm{NH}_{4}^{+} \mathrm{S}$ treatment was sediment collected from Las Flores stream, whereas in the pots destined to 
the $\mathrm{NH}_{4}^{+} \mathrm{A}$ treatment, stream sediments were replaced by $95 \mathrm{~g}$ of sand washed with $5 \% \mathrm{HCI}$. Control vessels had pots with sediments but no shoots, and were used to detect potential release of inorganic nitrogen from sediments to the overlying water. Nitrogen concentration of Knop solution in treatments $\mathrm{NO},-, \mathrm{NH}_{4}{ }^{+} \mathrm{S}$ and $\mathrm{NH}_{4}^{+} \mathrm{A}$

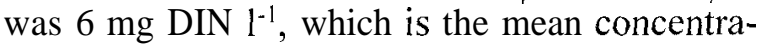
tion of soluble inorganic nitrogen observed in the Las Flores stream (Feijoó et al., 1996). SRP concentration in all treatments was $1 \mathrm{mg} \mathrm{l}^{-1} \mathrm{P}_{-} \mathrm{PO}_{4}$.

Treatments were designed to estimate:

a) nitrogen uptake from sediment by $E$. densa in absence of foliar absorption $\left(\mathrm{H}_{2} \mathrm{O}\right.$ treatment);

b) foliar absorption of nitrate in presence of sediment $\left(\mathrm{NO}_{3}^{-}\right.$treatment); and

c) foliar absorption of ammonium in presence and absence of sediment $\left(\mathrm{NH}_{4}{ }^{+} \mathrm{S}\right.$ and $\mathrm{NH}_{4}{ }^{+} \mathrm{A}$ treatments, respectively).

Nitrate, nitrite, and ammonium concentrations were determined in each treatment at the beginning and end of the experiment (i.e. after 7 days). Initial and final shoot biomass, nitrogen concentration in plant and sediments, and ammonium concentration in interstitial water were also measured, in 3 replicates of plants and sediments.

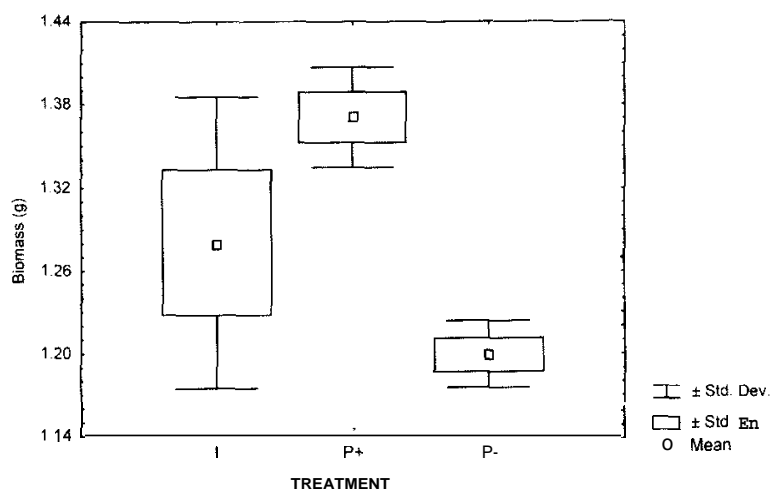

Figure 1. Boxplot of E. densa biomass at the beginning and at the end of the experiment $\mathrm{I}$ in each treatinent $\left(\mathrm{P}^{+}\right.$and $\left.\mathrm{P}^{-}\right)$. Boxplot de las biomasas de E. densa al principio (I) y al final del experimento I en cada tratamiento $(P+y$ - $)$.

\section{RESULTS}

\section{Experiment 1: phosphorus absorption}

SRP in water decreased significantly during the experiment $(\mathrm{p}<0.001)$, but no significant differences in SRP concentrations were detected between treatments. Almost all SRP had apparently been absorbed by $E$. densa in both treatments. Control vessels showed no variations in water SRP concentration (Table 3 ). This indicates that there was no exchange of phosphorus between water and sediments. Water temperature during the experiment was always below $25{ }^{\circ} \mathrm{C}$.

At the end of the experiment, E. densa biomass differed significantly between treatments $(\mathrm{p}<$ $0.05)$. However, no differences were apparent between initial and final biomass. Differences may have been masked by high variance associated to initial biomass values (see Fig. 1 and Table 3). Tissue $\mathrm{P}$ concentration in E. densa decreased during the experiment in the $P^{-}$treatment $(\mathrm{p}<0.05)$, while no change was observed in the $P^{+}$treatment. Total phosphorus content (i.e. biomass times tissue $\mathrm{P}$ concentration) increased in the $P^{+}$treatment $(\mathrm{p}<0.1)$ through the experiment and decreased in the $P^{-}$treatment $(\mathrm{p}<0.05)$. In P-pots, plant biomass showed a net loss of phosphorus (Table 3 ).

SRP concentration in interstitial water increased in both treatments during the experiment $(\mathrm{p}<0.05)$. Sediment TP concentration did not change significantly during the experiment nor between treatments (Table $\mathbf{3}$ ).

Phosphorus absorption rates by $E$. densa from water were one order of magnitude greater than those from sediments (Table 4). Although both treatments had different SRP concentration in water, absorption rates from water and sediments did not differ significantly between treatments.

\section{Experiment II: nitrogen absorption}

Dissolved inorganic nitrogen concentration in water (i.e. the sum of nitrates, nitrites, and ammonium) decreased significantly by the end 
Table 2. Experimental design. Phosphorus (in $\mathrm{mg} \mathrm{l}^{-1} \mathrm{P}-\mathrm{PO}$, ) and nitrogen (as ing $\mathrm{l}^{-1} \mathrm{~N}-\mathrm{NO}$; or $\mathrm{mg}^{-1} \mathrm{~N}^{-\mathrm{NH}_{4}}{ }^{\prime}$ ) concentrations in Knop solution for each treatment. Substrate used in each treatment is also indicated. Control vessels had no plants. Diseño experimental. Para cada tra-

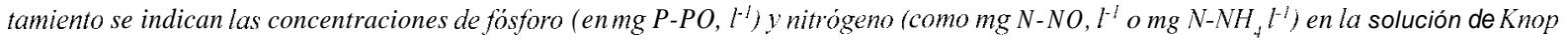
También se indica el tipo de substrato para cada tratamiento Los recipientes control no tenian pluntus.

\begin{tabular}{|c|c|c|c|c|c|}
\hline Experiment & Treatment & $\begin{array}{l}\text { Phosphorus } \\
\text { concentration }\end{array}$ & $\begin{array}{c}\text { Nitrogen } \\
\text { concentration }\end{array}$ & substrate & $\begin{array}{l}\text { number of } \\
\text { replicates }\end{array}$ \\
\hline \multirow[t]{4}{*}{ I } & $P^{+}$ & 0.3 & 7.14 (1) & sediment & 4 \\
\hline & $P$ & 0.15 & $7.14(1)$ & sediment & 4 \\
\hline & $P^{\prime}$ control & 0.3 & $7.14(1)$ & sediinent & 1 \\
\hline & $P$ control & 0.15 & $7.14(1)$ & sediment & 1 \\
\hline \multirow[t]{5}{*}{ II } & $\mathrm{H}_{2} \mathrm{O}$ & 1 & 0 & sediment & 3 \\
\hline & $\mathrm{NO}_{3}^{-}$ & 1 & $6(1)$ & sediment & 3 \\
\hline & $\mathrm{NH}_{4}^{+} \mathrm{S}$ & 1 & $6(2)$ & sediment & 3 \\
\hline & $\mathrm{NH}_{4}^{+} \mathrm{A}$ & 1 & $6(2)$ & sand & 3 \\
\hline & control & 0 & 0 & sediment & 2 \\
\hline
\end{tabular}

(1) in $\mathrm{mg} \mathrm{l}^{-1} \mathrm{~N}-\mathrm{NO}$;

(2) in $\mathrm{mg} \mathrm{l}^{-1} \mathrm{~N}-\mathrm{NH}_{4}^{+}$

ofthe experiment $(\mathrm{p}<0.05)$ in the $\mathrm{NO} ; \mathrm{NH}_{4}{ }^{+} \mathrm{S}$, and $\mathrm{NH}_{4}^{+} \mathrm{A}$ treatments (Fig. 2). This decrease was lower in the $\mathrm{NO}_{3}^{-}$treatment than in the $\mathrm{NH}_{4}{ }^{+} \mathrm{S}$ and $\mathrm{NH}_{4}{ }^{\prime} \mathrm{A}$ treatments. There were no significant differences between the $N H, S$ and $\mathrm{NH}_{4}^{+} \mathrm{A}$ treatments. The dissolved inorganic nitrogen concentration in control vessels did not vary significantly through the experiment, indicating that there was no release of nitrogen from sediments to water (Fig. 2).

Dissolved oxygen concentration in water was relatively high in all vessels (i.e., it was in excess of $7 \mathrm{mg} \mathrm{l}^{-1}$.). In this experiment, water temperature did not exceed $27^{\circ} \mathrm{C}$. These conditions do not favour denitritication in water (Focht \& Verstraete, 1977).

No changes in biomass of $E$. densa could be detected through the experiment due to large variability of initial biomass. Plant biomass at the end of the experiinent showed significant differences between the $H, O$ and $N O$; treatments $(\mathrm{p}<$ $0.05)$. Tissue $\mathrm{N}$ concentration increased significantly during the experiment in the $\mathrm{NH}_{4} \mathrm{~S}$ and $\mathrm{NH}_{4}{ }^{+} \mathrm{A}$ treatments $(\mathrm{p}<0.05)$ (Table 5). Total nitrogen (TN) content in tissue of $E$. densa did not vary significantly during the experiment, as also observed with plant biomass. However, sig- nificant differences ainong treatments were apparent by the end of the period, being significantly lower in the $H, O$ treatment, interinediate in the $\mathrm{NO}_{3}{ }^{-}$treatinent and higher in the $\mathrm{NH}_{4}{ }^{+} \mathrm{S}$ and $\mathrm{NH}_{4}{ }^{+} \mathrm{A}$ treatments $(\mathrm{p}<0.05)$ (Fig. 3 and Table 5).

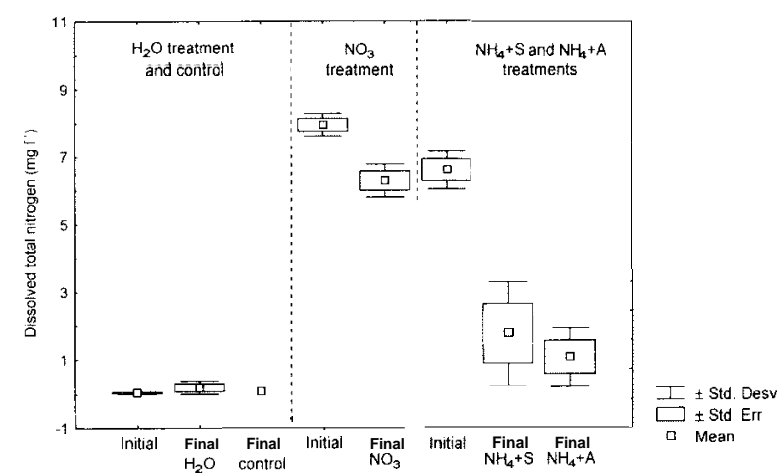

Figure 2. Boxplot of dissolved inorganic nitrogen coricentration (i.e. nitrate + nitrite + ammonium) in treatments at the beginning and ai the end of experiment II. $\mathrm{n}=\mathbf{3}$, with ihe exceptioii of controls, where $\mathrm{n}=2$. Boxplot de la concentración de nitrógeno inorgánico disuelto (estimado como la sumu de nitratos, nitritos y amonio) en los distintos tratamientos al comenzar y al finalizar el experimento II. $n=3$. con excepción de los controles donde $n=2$. 
Table 3. Values of the variables deterrnined (water SRP, plant biomass, water phosphorus concentration, total tissue-P content, interstitial water SKP and total P) at the beginning (Initial) and at the eiid of the experiment l (one week) in both treatments $\left(P^{+}\right.$and $P^{-}$) and in the controls (C). Means and standard errors (hetweeii brackets) are indicated $(\mathrm{n}=4)$. Valores medios de las variables determinadas al inicio (lnitial) y al final del experimento l para ambos tratamientos $(P \dashv$ y $P$-) y en los controles $(C)$. Se indican los valores medios y los errores estandar (entre paréntesis) $(n=4)$.

\begin{tabular}{|c|c|c|c|c|c|}
\hline Compartment & Variable & Initial & $C$ & $P$ & $P$ \\
\hline Water & $\operatorname{SRP}\left(\mathrm{mg} \mathrm{l}^{-1}\right)$ & $\begin{array}{c}P^{\prime}=0.30 \\
(0.001) \\
P^{-}=0.15 \\
(0.001)\end{array}$ & $\begin{array}{c}P=0.30 \\
(0.001) \\
P=0.14 \\
(0.002)\end{array}$ & $\begin{array}{c}0.014 \\
(0.001)\end{array}$ & $\begin{array}{c}0.014 \\
(0.001)\end{array}$ \\
\hline \multirow[t]{3}{*}{ E. densa } & Biomass (g DW) & $\begin{array}{c}1.280 \\
(0.053)\end{array}$ & & $\begin{array}{c}1.371 \\
(0.018)\end{array}$ & $\begin{array}{r}1.199 \\
(0.012)\end{array}$ \\
\hline & $\begin{array}{l}\text { Phosphorus } \\
\text { concentration (ing } \mathrm{g}^{-1} \text { ) }\end{array}$ & $\begin{array}{c}7.125 \\
(0.059)\end{array}$ & & $\begin{array}{c}7.175 \\
(0.073)\end{array}$ & $\begin{array}{c}6.688 \\
(0.088)\end{array}$ \\
\hline & $\begin{array}{l}\text { Total phosphorus } \\
\text { content (mg) }\end{array}$ & $\begin{array}{c}9.116 \\
(0.340)\end{array}$ & & $\begin{array}{c}9.843 \\
(0.140)\end{array}$ & $\begin{array}{c}8.019 \\
(0.160)\end{array}$ \\
\hline \multirow[t]{2}{*}{ Sediments } & $\begin{array}{l}\text { lnterstitial water } \\
\operatorname{SRP}\left(\mathrm{mg} \mathrm{l}^{1}\right)\end{array}$ & $\begin{array}{c}0.099 \\
(0.010)\end{array}$ & $\begin{array}{c}0.135 \\
(0.019)\end{array}$ & $\begin{array}{c}0.142 \\
(0.007)\end{array}$ & $\begin{array}{c}0.138 \\
(0.001)\end{array}$ \\
\hline & $\begin{array}{l}\text { Total phosphorus } \\
\left(\mathrm{mg} \mathrm{g}^{-1}\right)\end{array}$ & $\begin{array}{c}0.493 \\
(0.035)\end{array}$ & $\begin{array}{c}0.492 \\
(0.068)\end{array}$ & $\begin{array}{c}0.421 \\
(0.012)\end{array}$ & $\begin{array}{c}0.407 \\
(0.013)\end{array}$ \\
\hline
\end{tabular}

Ammoniuin concentration in interstitial water decreased by the end of the experiment $(\mathrm{p}<$ 0.05 ), attaining levels close to zero in all treatments. TN concentration in sediments, however, did not vary significantly through the course of

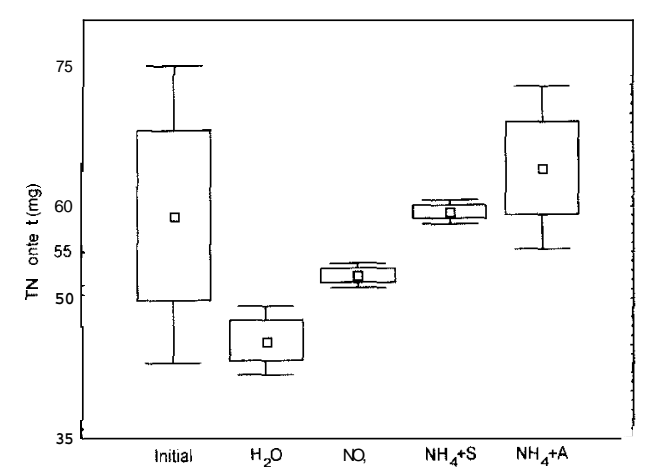

$I \pm$ Std. Desv
$\square+$ Std Err. Mean

Figure 3. Boxplot of $\mathrm{TN}$ content in $E$. densa at the beginning (Initial) and at the end of the experiment 11 in the different treatments. Boxplot de contenido tisular de nitrógeno de E. densa al comenzar (Initial) y al finalizar el experimento II en los distintos tratamientos. the experiment. Still, TN concentration in sediments in the $\mathrm{H}_{2} \mathrm{O}$ treatment increased $(\mathrm{p}<0.05)$ (Table 5).

The rate of $\mathrm{n}$ itrogen absorption from water was lower in the NO; treatment than in the $\mathrm{NH}_{4}{ }^{\prime} \mathrm{S}$ and $\mathrm{NH}_{4}{ }^{\prime} \mathrm{A}$ treatments $(\mathrm{p}<0.05)$. Differences in absorption rate between the latter two treatments were not significant (Table 4).

\section{DISCUSSION}

\section{Relative irnportance of water and sediments as source of nutrients}

Nutrient uptake in submerged macrophytes and the relative irnportance of water and sediments have been studied by several authors (Nichols \& Keeney, 1976a; Nichols \& Keeney, 1976b; Best \& Mantai, 1978; Carignan \& Kalff, 1980; Carignan, 1982; Gabrielson et al., 1984; Rørslett et al., 1986; Chambers et al., 1989; Rattray et al., 
Table 4. Absorption rates ofphosphorus and nitrogen from water and sediments in $E$. densa estimated in experiments. Values are expressed in $\mathrm{g} \mathrm{DW}^{-1}$ day $^{-1}$, and means and standard errors (between brackets) are indicated. $\mathrm{n}=4$ for experiment I and $\mathrm{n}=\mathbf{3}$ for experiment II. Estima de las tasas de absorción experimental de fósforo y nitrógeno en $\mathbf{E}$. densa Se indican los valores medios y los errores estándar lentre paréntesis) en gPS día-'. $n$. 4 para el experimento I y 3 para el Il.

\begin{tabular}{|c|c|c|c|c|c|}
\hline \multirow{2}{*}{$\begin{array}{c}\text { Experiment } \\
\text { I }\end{array}$} & \multirow{2}{*}{$\begin{array}{c}\text { Treatment } \\
P_{+}\end{array}$} & \multicolumn{2}{|c|}{$\begin{array}{l}\text { Abcorption rates of nitrogen } \\
\text { water }\end{array}$} & \multicolumn{2}{|c|}{ Absorption rates of phosphorus } \\
\hline & & $\longrightarrow$ & $\longrightarrow$ & 0.196 & 0.017 \\
\hline & & & $(0.001)$ & $(0.003)$ & \\
\hline & $P-$ & & - & 0.191 & 0.022 \\
\hline & & & $(0.004)$ & $(0.004)$ & \\
\hline \multirow[t]{4}{*}{ II } & $\mathrm{H}_{2} \mathrm{O}$ & $\begin{array}{c}0.010 \\
(0.009)\end{array}$ & $(*)$ & & \\
\hline & $\mathrm{NO}$ & $\begin{array}{c}0.020 \\
(0.004)\end{array}$ & $\begin{array}{c}0.009 \\
(0.006)\end{array}$ & & \\
\hline & $\mathrm{NH}_{4}{ }^{+} \mathrm{S}$ & $\begin{array}{c}0.111 \\
(0.028)\end{array}$ & $\begin{array}{c}0.001 \\
(0.001)\end{array}$ & 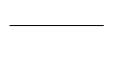 & - \\
\hline & $\mathrm{NH}_{+}{ }^{+} \mathrm{A}$ & $\begin{array}{c}0.125 \\
(0.013)\end{array}$ & $\longrightarrow$ & - & \\
\hline
\end{tabular}

$\left({ }^{*}\right)$ There was no absorption

1991; Pelton et al., 1998). Most of these studies concluded that sediments are the main source of nitrogen and phosphorus for submerged macrophytes (Table 6).
The analysis of the information presented in Table 6 shows that the relative importance of water as source of nutrients for macrophytes seems to vary with concentration, as Carignan

Table 5. Values of the variables determined (plant bioinass, water nitrogen concentration, total tissue-N content, interstitial water ammonium concentration and total $\mathrm{N}$ ) at the beginning (Initial) and at the end of ihe experiment II in the different treatments $\left(\mathrm{H}_{,} \mathrm{O}_{,} \mathrm{NO}_{3}, \mathrm{NH}_{4}^{-} \mathrm{S}\right.$ and $\left.\mathrm{NH}_{+}^{+} \mathrm{A}\right)$. Means and standard errors (between brackets) are indicated $(\mathrm{n}=3)$. Valores de las variables determinadas al inicio (initial) y al final del experimento II para los diferentes tratamientos $\left(\mathrm{H}_{2} \mathrm{O}, \mathrm{NO}, \mathrm{NH}_{4}+\mathrm{Sy} \mathrm{NH}_{4}{ }^{\mathrm{A}} \mathrm{A}\right)$. Se indican las medias y los errores estandar (entre paréntesis) (n 3).

\begin{tabular}{|c|c|c|c|c|c|c|}
\hline Compartment & Variable & Initial & $\mathrm{H}_{2} \mathrm{O}$ & $\mathrm{NO}_{3}$ & $\mathrm{NH}_{4}+\mathrm{S}$ & $\mathrm{NH}_{4}+\mathrm{A}$ \\
\hline \multirow[t]{3}{*}{ E. densa } & Biomass (g DW) & $\begin{array}{c}1.681 \\
(0.133)\end{array}$ & $\begin{array}{c}1.432 \\
(0.034)\end{array}$ & $\begin{array}{c}1.610 \\
(0.032)\end{array}$ & $\begin{array}{c}1.498 \\
(0.042)\end{array}$ & $\begin{array}{c}1.679 \\
(0.149)\end{array}$ \\
\hline & $\begin{array}{l}\text { Nitrogen } \\
\text { concentration } \\
\left(\mathrm{mg} \mathrm{g}^{-1}\right)\end{array}$ & $\begin{array}{l}32.50 \\
(0.65)\end{array}$ & $\begin{array}{l}31.78 \\
(0.76)\end{array}$ & $\begin{array}{l}32.67 \\
(1.01)\end{array}$ & $\begin{array}{l}39.65 \\
(0.66)\end{array}$ & $\begin{array}{l}38.23 \\
(0.68)\end{array}$ \\
\hline & $\begin{array}{l}\text { Total nitrogen } \\
\text { content }(\mathrm{mg})\end{array}$ & $\begin{array}{l}59.12 \\
(9.24)\end{array}$ & $\begin{array}{c}45.5 \\
(2.14)\end{array}$ & $\begin{array}{l}52.53 \\
(0.75)\end{array}$ & $\begin{array}{l}59.37 \\
(0.76)\end{array}$ & $\begin{array}{l}64.09 \\
(5.08)\end{array}$ \\
\hline \multirow[t]{2}{*}{ Sediments } & $\begin{array}{l}\text { Interstitial water } \\
\text { ammonium }\left(\mathrm{mg} \mathrm{l}^{-1}\right)\end{array}$ & $\begin{array}{c}0.615 \\
(0.120)\end{array}$ & $\begin{array}{c}0.022 \\
(0.004)\end{array}$ & $\begin{array}{c}0.022 \\
(0.001)\end{array}$ & $\begin{array}{c}0.013 \\
(0.005)\end{array}$ & \\
\hline & $\begin{array}{l}\text { Total nitrogen } \\
\left(\mathrm{mg} \mathrm{g}^{-1}\right)\end{array}$ & $\begin{array}{c}0.480 \\
(0.012)\end{array}$ & $\begin{array}{c}0.587 \\
(0.041)\end{array}$ & $\begin{array}{c}0.432 \\
(0.042)\end{array}$ & $\begin{array}{c}0.505 \\
(0.035)\end{array}$ & — \\
\hline
\end{tabular}


(1982) pointed out for the case of phosphorus. He proposed an empirical model to estimate the relative irnportance of roots in phosphorus uptake by macrophytes, which depends exclusively on the relative SRP concentration in water and sediments. In general, most experiments have been carried out under low nutrient levels in water, and macrophytes obtained phosphorus and nitrogen largely from sediments. The general reliance of lacustrine macrophytes on sediments as a phosphorus source is explained by the relative scarcity of SRP in lake water, compared to the much higher SRP concentrations of the interstitial water typical in anaerobic organic sediments. Pelton et al. (1998), however, contended that the water may be a main source of phosphorus in lotic environments because SRP concentrations are generally higher in flowing than in quiescent waters, sediments are aerobic, and diffusive boundary levels around plant shoots are thinner.

Carignan \& Kalff (1980) contended that sediments constitute the only significant source of phosphorus for rooted macrophytes in both oligotrophic and mildly eutrophic lakes (i.e. [SRP] $<0.2 \mathrm{mg} \mathrm{l}^{-1}$ ), characterized by relatively high interstitial water SRP concentrations. They concluded that rooted macrophytes took up significant phosphorus amounts only in hypereutrophic waters. Thus, the relative contribution of water and sediments as source of $\mathrm{P}$ for submerged plant growth appears to be a function of relative phosphorus availability in sediment and water.

Nutrient concentrations in water and sediments in our experiments represent the nutrient levels usually observed in Pampean streams where $E$. densa grows. Phosphorus concentrations were similar to those used by Pelton et al. (1998) and Carignan (1982), who found that water was the main source of phosphorus for plant growth. Dissolved nitrogen concentrations in water used in our experiments were higher than those generally reported (Table 6). The model of Carignan (1982) applied to our data predicts that between $23 \%$ and $34 \%$ of the phosphorus taken by $E$. densa will be absorbed by roots. This suggests that water can be the main source of phosphorus and nitrogen for E. densa. In Pampean nutrient- rich streams, water flow provides an abundant and continuous supply of nutrients.

Velocities of nutrient absorption estimated for $E$. densa in our experiments agrees well with those reported in the literature. Nitrogen uptake from sediments determined by Toetz (1974), however, was clearly larger than in our experiment (Table 7).

\section{Nutrient absorption from water}

Our results indicate that $E$. densa rapidly absorbs SRP from water, and that different SRP levels in water produce significant differences in the inacrophytic biomass and tissue $\mathrm{P}$ content. According to Bristow (1975), foliar uptake of phosphorus by $E$. densa is not affected by the removal of roots.

E. densa absorbed more nitrogen as ammoniuin than as nitrate in our experiments as it is evident by comparing water DIN, tissue $\mathrm{N}$ and $\mathrm{N}$ absorption rates from water in $\mathrm{NO}_{3}^{-}, \mathrm{NH}_{4}{ }^{+} \mathrm{S}$ and $\mathrm{NH}, \mathrm{A}$ treatments. This has also been shown by Reddy et al. (1987). Larger uptake of ammonium than of nitrate by plants did not increase their biomass. However, more accumulation of nitrogen in plant tissues resulted when fed $\mathrm{NH}$,' than when fed $\mathrm{NO}_{3}^{-}$. An increase in tissue $\mathrm{N}$ concentration, but not in biomass, was also reported by Howard-Williams (1981) in a population of Potamogeton pectinatus exposed to nutrient enrichment, and is normally taken to indicate that plants are not N-limited (Gerloff \& Krombholz, 1966).

A preference for ammonium over nitrate has also been observed in other subinerged macrophytes, such as Ceratophyllum demersum (Toetz, 1971) and Myriophyllum spicatum (Nichols \& Keeney, 1976b). In $C$ demersum, nitrate uptake has been found to correlate with light intensity, practically ceasing in the dark, while ammonium uptake was continuous and decreased only slightly at night (Toetz, 1971). Nitrate has to be reduced to ammonium before it can be used for building bioinass, needing energy for this transforination. Similarly for $E$. densa, this could 
Table 6. Main source (i.e. water and/or sediments) of phosphorus and nitrogen in submerged macrophytes according to several authors. Phosphorus concentration in water is given as SRP or total phosphorus (TP concentrations are indicated in brackets). Sediment nutrient concentration is expressed in $\mathrm{mg} \mathrm{l}^{-1}$ (SRP and ammonium concentrationsin the interstitial water) or in $\mathrm{mg} \mathrm{g}^{-1} \mathrm{DW}$ (TP and TN). Principal aporte de fósforo y nitrógeno en los macrófitos sumergidos según algunos autores y los resultados de nuestros experimentos. La concentración de fósforo en el agua se expresa como SRP o fósforo total (en este caso, TP se indica entre paréntesis). Lu concentración de nutrientes en el sedimento se expresa en $\mathrm{mg} \mathrm{l}^{-1}$ (cuando se ha medido como concentración de SRP o de amonio en el ugua intersticial) o en mg $g^{-1}$ PS (cuando se ha medido como TPó TN).

\begin{tabular}{|c|c|c|c|c|c|}
\hline Species & Nutrient & Water concen- & $\begin{array}{l}\text { Sediment } \\
\text { tration }\left(\mathrm{mg} \mathrm{l}^{-1}\right)\end{array}$ & $\begin{array}{l}\text { Nutrient } \\
\text { concentration }\end{array}$ & $\begin{array}{l}\text { Reference } \\
\text { cource }\end{array}$ \\
\hline $\begin{array}{l}\text { Myriophyllum } \\
\text { spicatum }\end{array}$ & $\begin{array}{l}\mathrm{P} \\
\mathrm{N}\end{array}$ & $\begin{array}{l}0.009-0.178 \\
0.09-25.9(1)\end{array}$ & $\begin{array}{l}\text { iiot indicated } \\
\text { not indicated }\end{array}$ & $\begin{array}{l}\text { sediments } \\
\text { cediments or water }(3)\end{array}$ & $\begin{array}{l}\text { Best and Mantai } \\
\text { (1978) }\end{array}$ \\
\hline M. spicutum & $\mathrm{N}$ & $0.02-0.1(2)$ & $1.2-29.6 \mathrm{mg} \mathrm{l}^{-1}$ & cediments & $\begin{array}{l}\text { Nichols and Keeney } \\
(1976 \mathrm{a})\end{array}$ \\
\hline M. spicutum & $\mathrm{N}$ & $0.48(2)$ & $15.64 \mathrm{mg} \mathrm{l}^{-1}$ & water & $\begin{array}{l}\text { Nichols and Keeney } \\
(1976 b)\end{array}$ \\
\hline$M$ spicatum & $\mathrm{P}$ & $\begin{array}{l}0.0005 \\
0.0019 \\
0.167\end{array}$ & $\begin{array}{l}0.80 \mathrm{ing} \mathrm{g}^{-1} \\
0.80 \mathrm{mg} \mathrm{g}^{-1} \\
1.20 \mathrm{mg} \mathrm{g}^{-1}\end{array}$ & $\begin{array}{l}\text { cediments } \\
\text { sediments } \\
\text { sediments or water }\end{array}$ & $\begin{array}{l}\text { Carignan and } \\
\text { Kalff (1980) }\end{array}$ \\
\hline $\begin{array}{l}\text { M. triphyllum } \\
\text { Lagarosiphon } \\
\text { major }\end{array}$ & $\begin{array}{l}\mathrm{P} \\
\mathrm{N} \\
\mathrm{P} \\
\mathrm{N}\end{array}$ & $\begin{array}{l}0.001 \\
0.006 \\
0.009-0.038(2) \\
0.001 \\
0.006 \\
0.009-0.038(2)\end{array}$ & $\begin{array}{l}0.06-0.7 \mathrm{mg} \mathrm{g}^{-1} \\
0.06-0.7 \mathrm{mg} \mathrm{g}^{-1} \\
0.06-0.94 \mathrm{mg} \mathrm{g}^{-1} \\
0.12-0.86 \mathrm{mg} \mathrm{g}^{-1} \\
0.12-0.86 \mathrm{mg} \mathrm{g}^{-1} \\
1.11-3.02 \mathrm{mg} \mathrm{g}^{-1}\end{array}$ & $\begin{array}{l}\text { cediments } \\
\text { sedimente or water } \\
\text { sediments or water } \\
\text { cediments } \\
\text { sedimente or water } \\
\text { sedimente or water }\end{array}$ & $\begin{array}{l}\text { Rattray et al. } \\
\text { (1991) }\end{array}$ \\
\hline Elodea canadensis & $\mathrm{P}$ & $0.013(\mathrm{TP})$ & not indicated & cediments & $\begin{array}{l}\text { Rorslett et al. } \\
\text { (1986) }\end{array}$ \\
\hline $\begin{array}{l}\text { E. canadensis } \\
\text { Potamogeton } \mathrm{sp}\end{array}$ & $\mathrm{P}$ & $0.07-0.57$ & $0.01-0.07 \mathrm{mg} \mathrm{l}^{-1}$ & water & $\begin{array}{l}\text { Pelton et al. } \\
\text { (1998) }\end{array}$ \\
\hline $\begin{array}{l}\text { Vallisneria ameri- } \\
\text { cana, A4 spicatum }\end{array}$ & $\mathbf{P}$ & 0.167 & $0.174 \mathrm{mg} \mathrm{l}^{-1}$ & water & $\begin{array}{l}\text { Carignan } \\
(1982)\end{array}$ \\
\hline $\begin{array}{l}\text { Potamogeton } \\
\text { crispus }\end{array}$ & $\begin{array}{l}\mathrm{P} \\
\mathrm{N}\end{array}$ & $\begin{array}{l}0.005-0.12 \\
0.25-0.5(4)\end{array}$ & $\begin{array}{l}0.26-0.60 \mathrm{ing} \mathrm{g}^{-1} \\
0.11-0.71 \mathrm{mg} \mathrm{g}^{-1}\end{array}$ & $\begin{array}{l}\text { sedimente } \\
\text { sedimente }\end{array}$ & $\begin{array}{l}\text { Chainbers et } \\
\text { al. }(1989)\end{array}$ \\
\hline E. densa & $\mathrm{P}$ & $0.06-0.066(\mathrm{TP})$ & $0.097 \mathrm{mg} \mathrm{l}^{-1}$ & cediments & Gabrielcon et al (1984) \\
\hline E. densa & $\mathrm{P}$ & $0.15-0.30$ & $\begin{array}{l}0.49 \mathrm{mg} \mathrm{g}^{-1} \\
0.10 \mathrm{mg} \mathrm{l}^{-1} \\
0.48 \mathrm{mg} \mathrm{g}^{-1}\end{array}$ & water & $\begin{array}{l}\text { Experiment II } \\
0.30 \mathrm{mg} \mathrm{l}^{-1}\end{array}$ \\
\hline
\end{tabular}

(1) As nitrate.

(2) As nitrate + ammonium

(3) Depending on nitrate concentration in the water.
(4) As dissolved total nitrogen.

(5) Dissolved inorganic nitrogen. 
Table 7. Absorption velocities ofnitrogen and phosphorus (in $\mathrm{mg} \mathrm{g}^{-1} \mathrm{DW}$ day ${ }^{-1}$ ) from water and sediments by $E$. densa, gleaned from the literature and obtained from our experiments. Initial phosphorus concentration is given as water SRP, unless otherwise stated. Velocidudes de ubsorción del nitrógeno y el fósforo (en $\mathrm{mg} \mathrm{g}^{-1} P S$ día $^{-1}$ ) del agua y sedimento por $\mathbf{E}$. densa. estimadas por otros autoresy en nuestros experimentos Lu concentración inicial defósforo se expresa como SRP, a menos que se indique lo contrario.

\begin{tabular}{|c|c|c|c|c|}
\hline Reference & Treatment & $\begin{array}{l}\text { lnitial nutrient } \\
\text { concentration }\left(\mathrm{mg} \mathrm{l}^{-1}\right)\end{array}$ & $\begin{array}{l}\text { Absorption velocity } \\
\text { water }\end{array}$ & sediments \\
\hline \multicolumn{5}{|l|}{ PHOSPHORIS } \\
\hline Reddy et al (1 987) & - & 3.0 & $0.11-0.26$ & $\longrightarrow$ \\
\hline Gabrielson et al (1984) & $\longrightarrow$ & $0.06(1)$ and $0.097(2)$ & $0.054-0.077$ & $0.304-0.374$ \\
\hline Experiment I & $\begin{array}{l}P \\
P\end{array}$ & $\begin{array}{l}0.30 \text { and } 0.10(2) \\
0.15 \text { and } 0.10(2)\end{array}$ & $\begin{array}{l}0.078 \\
0.039\end{array}$ & $\begin{array}{l}0.500 \\
0.637\end{array}$ \\
\hline \multicolumn{5}{|l|}{ NitROGEN } \\
\hline Reddy et al. (1987) & $\longrightarrow$ & $21.0(3)$ & $0.31-0.74$ & $\longrightarrow$ \\
\hline Toetz (1974) & $\begin{array}{l}\text { water (4) } \\
\text { sand (5) }\end{array}$ & $\begin{array}{l}0.5(6) \\
0.5(6)\end{array}$ & $\longrightarrow$ & $\begin{array}{c}19.53 \\
136.97\end{array}$ \\
\hline Experiment II & $\begin{array}{l}\mathrm{NO}_{3} \\
\mathrm{NH}_{4}{ }^{+} \mathrm{S} \\
\mathrm{NH}_{4}{ }^{+} \mathrm{A}\end{array}$ & $\begin{array}{l}7.94(7) \text { and } 0.30(8) \\
6.59(9) \text { and } 0.30(8) \\
6.59(9)\end{array}$ & $\begin{array}{l}0.360 \\
1.091 \\
1.177\end{array}$ & $\begin{array}{l}0.223 \\
0.038 \\
\end{array}$ \\
\hline
\end{tabular}

(1) dissolved TP in the water

(2) SRP in the sediment interstitial water

(3) nitrate + ammonium in the water

(4) roots submerged in water

(5) roots buried in sand

(6) ammonium in the water of the root compartment

(7) nitrate in the water

(8) ammonium in the sediment interstitial water

(9) ammonium in the water

explain the apparent preference for ammonium over nitrate as a nitrogen source.

\section{Nutrient absorption from sediments}

In our experiments, $E$. densa shoots were introduced into stream sediments, putting internal tissues in direct contact with the interstitial water. The use of apical shoots allowed to standardize experimental conditions, because shoots had the same length and lacked roots, which could vary in number and length.
Bristow \& Whitcombe (1971) reported that the lack of roots in shoots does not affect phosphorus absorption by the plant. They looked at phosphorus uptake by $E$. densa using ${ }^{32} \mathrm{P}$, observing that after 10 days, $74 \%$ of shoot TP derived from the stem base. Roots originally present, however, decayed during the course of the experiment. indicating a significant absorption of phosphorus by the lower part of the plant even in absence of roots. The authors concluded that the translocation of $\mathrm{P}$ from the basal to the apical zone will operate in much the satne manner in the absence of roots, though more slowly. 


\section{Comparison of phosphorus and nitrogen absorption in $E$. densa}

In our experiments, absorption rates from water and sediments were higher for phosphorus than for nitrogen. This suggests that mechanisms of uptake and retention are more efficient for phosphorus than for nitrogen in E. densa, even though nutrient concentrations in plant tissues in our experiments were well above the values established by Gerloff \& Krombholz (1966) as limiting (i.e. $13 \mathrm{mg} \mathrm{g}^{-1}$ for nitrogen and $1.3 \mathrm{mg}$ $\mathrm{g}^{-1}$ for phosphorus).

\section{CONCLUSIONS}

In Pampean streams, E. densa can absorb nutrients from both water and sediments. The comparison of our data with those obtained by other authors suggests that water can be the main source of nutrients for $E$. densa.

$E$. densa shows a preference for ammonium over nitrate. It absorbs rapidly the former ion when it is present in water, resulting in the accumulation of nitrogen in tissues but not leading to an increase in plant biomass. E. densa biomass seems to be more related to phosphorus concentration in water, given that different SRP levels in water coincided with different macrophytic biomass. The hypothesis of a greater dependence of $E$. densa on phosphorus is also supported by the higher absorption rates estimated for this nutrient in relation to nitrogen.

\section{ACKNOWLEDGEMENTS}

Gabriela Campana and Francisco Martinelli provided laboratory and field assistance, for which we are very grateful. We also thank Carlos Coviella for the revision of the English text. This work was supported by a grant of the Comisión de Investigaciones Científicas de la Provincia de Buenos Aires.

\section{REFERENCES}

ANDERSEN, J. M. 1976. An ignition method for the determination of total phosphorus in lake sediments. Wat. Res., 10:329-331.

AOAC. 1984. Official methods of analysis, Arlington: AOAC.

APHA. 1992. Standard methods for the examination of water and wastewater, Washington D.C.: APHA.

BARKO, J. W., D. GUNNISON. \& S. R. CARPENTER. 1991. Sediment interactions with submersed macrophyte growth and community dynamics. Aquat. Bot., 41: 41-65.

BARKO, J. W. \& SMART, R. M. 1986. Sedimentrelated mechanisms of growth limitation in submersed macrophytes. Ecology, 67:1328-1340.

BEST, M. D. \& K. MANTAI. 1978. Growth of Myriophyllum: Sediment or lake water as the source of nitrogen and phosphorus. Ecology, 59: 1075-1080.

BEST, E. P. H., H. WOLTMAN \& J. H. H. JACOBS. 1996. Sediment-related growth limitation of Elodea nuttalli as indicated by a fertilization experiment. Freshwater Biol., 36: 33-44.

BRISTOW, J. M. 1975. The structure and function of roots in aquatic vascular plants. In: The development and function of roots. J. G. Torrey \& D. T. Clarkson (eds.): 22 1-233. Academic Press, New York.

BRISTOW, J. J. \& M. WHITCOMBE. 1971. The role of roots in the nutrition of aquatic vascular plants. Amer. J Bot., 58: 8 -13.

CARIGNAN, R. 1982. An empirical model to estimate the relative importance of roots in phosphorus uptake by aquatic macrophytes. Can. J. Fish. Aquat. Sci., 39: 243-247.

CARIGNAN, R. \& R. KALFF. 1980. Phosphorus sources for aquatic weeds: Water or sediment? Science, 207: 987-989.

CARPENTER, S. R. \& D. M. LODGE. 1986. Effects of submersed macrophytes on ecosystem processes. Aquat. Bot., 26: 311-370.

CASO, O. H. 1954. Cultivo de Elodea densa en soluciones nutritivas. Revista de Investigaciones Agrícolas, 8: 35-50.

CHAMBERS, P.A., E. E. PREPAS, M. L. BOTHWELL \& H. R. HAMILTON. 1989. Roots versus shoots in nutrient uptake by aquatic macrophytes in flowing waters. Can. J. Fish. Aquat. Sci., 46: 435-439.

DUARTE, C. M., D. PLANAS \& J. PEÑUELAS. 1994. Macrophytes, taking control of an ancestral home. In: Limnology now: Apavadigm ofplanetary 
problems. R. Margalef (ed.): 59-79. Elsevier Science B.V., Amsterdam.

FAO. 1986. Manual of food quality control. 7. Food analysis: General techniques, additives, contaminants, and composition. Roma: FAO.

FEIJOÓ, C. S., F. R. MOMO, C. C. BONETTO \&. N. M. TUR. 1996. Factors influencing biomass and nutrient content of the submerged macrophyte Egeria densa Planch. in a pampasic stream. Hydrobiologia, 341:21-26.

FOCHT, D. D. \& W. VERSTRAETE. 1977. Biochemical ecology of nitrification and denitrification. In: Advances in Microbial Ecology, vol. 1. M. Alexander (ed.): 135-214. Plenum Press, New York.

GABRIELSON, J. O., M. A. PERKINS \& E. B. WELCH. 1984. The uptake, translocation and release of phosphorus by Elodea densa. Hydrobiologia, 111: 43-48.

GERLOFF, G. C. \& P. H. KROMBHOLZ. 1966. Tisue analysis as a measure of nutrient availability for the growth of angiosperm aquatic plants. Limnol. Oceanogr:, 11:529-537.

GETSINGER, K. D. 1982. The life cycle and physiology of the submersed angiosperm Egeria densa Planch in Lake Murion, South California. Ph.D. Dissertation, Clemson University. 104 pp.

HOWARD-WILLIAMS, C. 1981. Studies on the ability of a Potamogeton pectinatus community to remove dissolved nitrogen and phosphorus compounds from lake water. J. Appl. Ecol., 18: 619-637.

NICHOLS, D. S. \& D. R. KEENEY. 1976a. Nitrogen nutrition of Myriophyllum spicatum: variation of plant tissue nitrogen concentration with season and site in Lake Wingra. Freshwater Biol., 6: 137-144.

NICHOLS, D. S. \& D. R. KEENEY. 1976b. Nitrogen nutrition of Myriophyllum spicatum: uptake and translocation of ${ }^{15} \mathrm{~N}$ by shoots and roots. Freshwater Biol, 6: 145-154.

PELTON, D. K., S. N. LEVINE \& M. BRANER. 1998. Measurements of phosphorus uptake by macrophytes and epiphytes from the LaPlatte River (VT) using ${ }^{32} \mathrm{P}$ in stream microcosms. Freshwater Biol., 39: 285-299.

RATTRAY, M. R., C. HOWARD-WILLIAMS, C. \& J. M. A. BROWN. 1991. Sediment and water as sources of nitrogen and phosphorus for submerged rooted aquatic macrophytes. Aquat. Bot., 40: 225-237.

REDDY, K. R., J. C. TUCKER \& W. F. DEBUSK. 1987. The role of Egeria in removing nitrogen and phosphorus from nutrient enriched waters. $J$. Aquat. Plant Manage., 25: 14-19.

RØRSLETT, B., D. BERGE \& S. W. JOHANSEN. 1986. Lake enrichment by submersed macrophytes: a Norwegian whole-lake experience with Elodea canadensis. Aquat. Bot., 26: 325-340.

SIEGEL, S. 1986. Estadística no paramétrica aplicadaa las ciencias de la conducta. México D.F.: Trillas.

TOETZ, D. W. 1971. Diurnal uptake of NO; and $\mathrm{NH}_{4}^{+}$by a Ceratophyllum-periphyton community. Limnol. Oceanogr:, 16:819-822.

TOETZ, D. W. 1974. Uptake and translocation of ammonia by freshwater hydrophytes. Ecology, 55: 199-201.

WETZEL, R. G. \& G. E. LIKENS. 1991.Limnological analysis. New York: Springer-Verlag. 